\title{
THE 'PHARAOH' ANECDOTE IN PRE-MODERN ARABIC HISTORIOGRAPHY
}

\author{
Konrad Hirschler \\ SCHOOL OF ORIENTAL AND AFRICAN STUDIES, LONDON
}

This article examines the development of the pharaoh as a literary figure in Arabic historiography between the third/ninth and the ninth/fifteenth centuries. The first aim is to reflect upon the changing narrative structure of such anecdotes in texts ranging from the universal chronicle of al-Tabarī (d. 310/923) to the regional chronicle of al-Maqrīzī (d. 845/1442). The article's second concern is to evaluate the plurality of meanings that emerged from these changes. This discussion is then linked to detailed consideration of the authors' social contexts, with particular focus on that of al-Maqrīzì. The nexus between literary approach and social history that is proposed here offers a deeper understanding of the function of narrative resources that moved from text to text. Not only was this a salient feature of Arabic historiography, but also it allows us to reconsider the repeated appearance of such elements beyond describing them as simply 'borrowing' or 'copying'. Indeed, the discussion concludes that authors skilfully drew from a pool of narrative devices and artfully established intertextual allusions across both time and genres.

This study is situated within the stream of scholarship that has integrated literary concerns with the study of historiography over recent decades. ${ }^{1}$ This includes early representatives of an explicit move towards literary approaches in studying Arabic historical texts, such as that of Fähndrich, who asks how authors ascribed meaning via shaping of the text, most specifically by the interplay between 'factual' and 'illustrative' material. ${ }^{2}$ The most far-reaching writings in this stream of scholarship

1 This article developed out of an informal presentation at the Arabic Texts Seminar (Pembroke College, Oxford, May 2008) and a paper given at the workshop Arabic Pasts: Histories and Historiography (SOAS, London, September 2008). I would like to thank those present for their remarks; Gerald Hawting (SOAS) for commenting on an early draft version; the anonymous Journal of Arabic and Islamic Studies reviewers, and Matthias Determann (SOAS) for their remarks on the final version.

2 H. Fähndrich, 'The Wafayāt al-A A $^{c} y \bar{n}$ of Ibn Khallikān: A New Approach', Journal of the American Oriental Society, 93 (1973), 432-45; H. Fähndrich, 'Compromising the Caliph. Analysis of Several Versions of an Anecdote About Abū Dulāma and al-Manșūr', Journal of Arabic Literature, 8 
have been a series of publications by al-Azmeh in the 1980s, who read universal chronicles and biographical dictionaries primarily as literary texts. ${ }^{3}$ The last decade has witnessed the publication of studies that are less programmatic than al-Azmeh's, but rather apply literary approaches to concrete examples, such as for example, Leder's reflections on the interplay of factual and fictional elements in the early Arabic tradition. ${ }^{4}$ Of particular relevance for the following discussion are el-Hibri's study of 'Abbāsid historical writing and Shoshan's discussion of al-Tabarī's work. Both authors are, irrespective of different underlying approaches, concerned mainly with narrative means that are employed and the meanings that are ascribed to the narratives. ${ }^{5}$

(1977), 36-47. For a critique of his approach and a reading of biographical dictionaries that is informed by R. Barthes' reflections, see F. Malti-Douglas, 'Dreams, the Blind, and the Semiotics of the Biographical Notice', Studia Islamica, 51 (1980), 137-62.

3 A. Al-Azmeh, Al-Kitāba al-ta rīkhīya wa-l-ma rifa al-ta rīkhīya (Beirut, 1983); A. Al-Azmeh, 'L'annalistique entre l'histoire et le pouvoir: une conception de l'histoire sous-jacente aux chroniques, biographies et gestes dans l'aire culturelle arabo-islamique', in Histoire et Diversité des Cultures, ed. UNESCO (Paris, 1984), 95-116; A. Al-Azmeh, 'Historie et Narration dans l'Historiographie Arabe', Annales, 41 (1986), 411-31.

4 S. Leder, 'The Literary Use of the Khabar: A Basic Form of Historical Writing', in The Byzantine and Early Islamic Near East: Problems in the Literary Source Material, ed. A. Cameron and L. I. Conrad (Princeton, 1992), 277-315; ibid. (ed.), Story-Telling in the Framework of Non-Fictional Arabic Literature (Wiesbaden, 1998); ibid. (2005): The Use of Composite Form in the Making of the Islamic Historical Tradition', in On Fiction and adab in Medieval Literature, ed. P. Kennedy (Wiesbaden, 2005), 125-148.

5 T. El-Hibri, Reinterpreting Islamic Historiography. Harun al-Rashid and the Narrative of the 'Abbasid Caliphate (Cambridge and New York, 1999). B. Shoshan, Poetics of Islamic Historiography: Deconstructing Tabari's History (Leiden, 2004). An earlier example of the influence of the literary turn is alQaddūrī, 'A./al-H.. al-Mujāhid, 'Șurat al-Sūdān fī-l-khițāb al-Maghribī khilāl alqarn XVI: Numūdhaj Manāhil al-șafāo ${ }^{\circ}$ fì ma āthir mawālīnā al-shurafāo ${ }^{\supset}$ li- ${ }^{\mathrm{c}} \mathrm{Abd}$ al- ${ }^{\mathrm{c} A z \bar{z} \mathbf{z}}$ al-Fashtālī', in Histoire et linguistique. Texte et niveau d'interprétation, ed. A. Sebti (Rabat, 1992), 27-35. The earliest author who engaged with Hayden White's approach in the field of Middle Eastern history was M. R. Waldman, 'The Otherwise Unnoteworthy Year 711: A Reply to Hayden White', Critical Inquiry, 7 (1981), 784-92. For the increased role of 'meaning' in historical studies see U. Daniel, 'Clio unter Kulturschock. Zu den aktuellen Debatten der Geschichtswissenschaft', in Geschichte in Wissenschaft und Unterricht, 48 (1997), 195-218 and 259-78. For a discussion of how al- 
However, scholarship on Arabic historiography that is influenced by the literary turn has one decisive shortcoming, and that is the second point of departure in this study, namely the tendency to disregard social contexts in which the texts were produced. Of those studies that are inspired by approaches drawn from literary studies, one gains only a weak impression about who was producing these texts for whom somewhat following the linguistic turn's celebrated 'il n'y a rien hors du texte'. ${ }^{6}$ This is problematic as it is obviously a difficult endeavour to read meaning into a text when this is not underpinned by a consideration of the milieu of production and-ideally-milieus of receptions. The study of the reception of texts is an admittedly difficult task, but the milieu of production, on the contrary, is much more accessible and has increasingly come into focus. Shatzmiller, for example, is the prime example of those who have sought to establish carefully argued links between developments in the wider society and changes to historical writing. She shows how historical writing at the Merinid court of the eighth/fourteenth century developed as a break from the preceding Almohad tradition, for instance with regard to the formation of Morocco as an independent political unit. ${ }^{7}$ The seminal study within the social history approach is Khalidi's Arabic Historical Thought in the Classical Period. Despite serious shortcomings in his work, this study represents a substantial reorientation within the field. ${ }^{8} \mathrm{He}$ defines four epistemological 'canopies' that are, in turn, closely linked to social, political and economic developments which took place in respective societal environments. In the same vein, individual authors are contextualised with regard to their particular position in society. Nevertheless, in the same sense that the literary turn has given crucial

Mas ${ }^{\mathrm{c}} \overline{\mathrm{u}} \overline{\mathrm{i}} \mathrm{i}$ turned in his chronicle 'the raw material of history [...] into something meaningful', see J. S. Meisami, 'Mas ${ }^{\mathrm{c}} \overline{\mathrm{u}} \mathrm{i} \overline{\mathrm{l}}$ and the Reign of al-Amīn: Narrative and Meaning in Medieval Muslim Historiography', in On Fiction and Adab in Medieval Literature, ed. P. F. Kennedy (Wiesbaden, 2005), 149-176.

6 J. Derrida, La dissemination (Paris, 1972), 42.

7 M. Shatzmiller, L'Historiographie Mérinide. Ibn Khaldun et ses contemporains (Leiden, 1982).

8 T. Khalidi, Arabic Historical Thought in the Classical Period (Cambridge, 1994). The fundamental problems are that he disregards considerable parts of the secondary literature and abstains from discussing what he understands by the term 'historical thought'. For a detailed critique of his work, see S. Conermann, 'Einige allgemeine Überlegungen zum vormodernen "Historischen Denken” der Araber', Orientalische Literaturzeitung, 93 (1998) 141-157. 
insights from its perspective, but has not taken the social context of the texts' production into consideration, a study such as Khalidi's is as informative about social contexts as much as it is disregarding the texts themselves. Thus, to some degree, the two most important trends in the study of Arabic historiography have been developing in certain isolation from one another. ${ }^{9}$ This article aims to bridge the gap between these two approaches. I employed the proposed combination of literary approaches and social history in a previous publication that analysed two seventh/thirteenth-century texts and that linked the ways their authors employed narrative devices to their social contexts. ${ }^{10}$ The present discussion takes a different perspective as it analyses the role of one specific narrative element, the figure of the pharaoh, in a variety of texts written over a period of more than five centuries. The ensuing problem is that the appearance of this element cannot be set within the larger narrative structure of the respective works. However, the possibility to trace the course of this element's travel between different texts that were produced in various regions and periods allows insights into changing ascriptions of meaning that are lost when focusing on particular works. The specific literary device chosen here, allusions to the pharaoh in the form of metaphors or similes, is of no greater importance than other devices that can be found in the texts. However, as the following discussion will show, references to the pharaoh are particularly helpful in order to study literary structure and social context in pre-modern Arabic historiography.

\section{The pharaoh in Arabic historiography}

The considerable role which references to the pharaonic past played in the medieval Muslim period has been studied in depth. Haarmann especially worked on late medieval, mainly Muslim, views of pharaonic Egypt. Such studies show that the pharaonic past, despite the unequivocally negative depiction of the pharaoh in the Qur ${ }^{\circ} \bar{n}$ and in hadīth, was often perceived positively. ${ }^{11}$ 'This was, for example, visible

9 One of the exceptions is O. Weintritt, Formen spätmittelalterlicher islamischer Geschichtsdarstellung. Untersuchungen zu al-Nuwairī alIskandarānīs Kitāb al-ilmān und verwandten zeitgenössischen Texten (Beirut, 1992), who succeeds in striking the most convincing balance between social context and text.

10 K. Hirschler, Medieval Arabic Historiography: Authors as Actors (London, 2006).

11 The field of theology also shared the diversity of perceptions as visible in the debate over the question whether the Pharaoh had died as a Muslim or not. 
in treatises that defended pharaonica and criticised those who tried to destroy them. In addition, places associated with this period played an important role as holy sites where Muslims and Christians sought intercession, and pharaonic material was used as spolia in mosques in order to take possession of their spiritual powers. ${ }^{12}$

On this debate, see E. Ormsby, 'The Faith of the Pharaoh: A Disputated Question in Islamic Theory', Studia Islamica, 98/99 (2004), 5-28. That this debate was not limited to the scholarly realm is visible by an incident in eighth/fourteenth-century Damascus. Here, a tailor named Hasan was arrested because he had answered the question in the affirmative. After three days and some lashing this 'ignorant commoner' repented and admitted to the falsity of his beliefs. See Ismā̄īl b. ${ }^{~}$ Umar Ibn Kathīr (d. 774/1373) Al-Bidāya wa-lnihāaya fì-l-ta ${ }^{\mathrm{T}} \mathrm{r} k h$, eds. ${ }^{\mathrm{C}} \mathrm{Alī} \mathrm{N}$. Ațwī et al., 14 vols. (Beirut, 1988), XIV, 286-7 and 289.

12 Haarmann's most important publications on this issue include, 'Die Sphinx. Synkretistische Volksreligiosität im spätmittelalterlichen islamischen Ägypten', Saeculum, 29 (1978), 367-84; 'Der Schatz im Haupte des Götzen', in Die islamische Welt zwischen Mittelalter und Neuzeit. Festschrift für Hans Robert Roemer zum 65. Geburtstag, ed. U. Haarmann and P. Bachmann (Wiesbaden/Beirut, 1979), 198-221; 'Regional Sentiment in Medieval Islamic Egypt', Bulletin of the School of Oriental and African Studies, 43/1 (1980), 5566; 'Heilszeichen im Heidentum - Muhammad-Statuen aus vorislamischer Zeit', Welt des Islams, 28 (1988), 210-24; 'Das pharaonische Ägypten bei islamischen Autoren des Mittelalters', in Zum Bild Ägyptens im Mittelalter und in der Renaissance, ed. E. Hornung (Fribourg and Göttingen, 1990), 29-58; 'In Quest of the Spectacular: Noble and Learned Visitors to the Pyramids Around 1200AD', in: Islamic Studies Presented to Charles J. Adams, ed. W. B. Hallaq and D. P. Little (Leiden, 1991) 57-67; 'Medieval Muslim Perceptions of Pharaonic Egypt', in Ancient Egyptian Literature: History and Forms, ed. A.

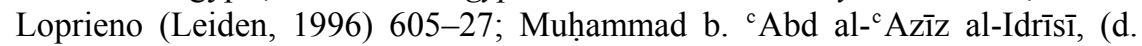
649/1251) Anwār ' ${ }^{c}$ ulwìy al-ajrām fi-l-kashf ${ }^{c}$ an asrār al-ahrām (Lights of the Translunar Bodies: On Uncovering the Secrets of the Pyramids), ed. U. Haarmann (Beirut 1991).

Some translations of medieval Arabic texts on the pyramids into German can be found in P. Franke, 'Orte verborgenen Wissens: Die ägyptischen Pyramiden aus Sicht der mittelalterlichen Araber', in Vom Nil an die Saale: Festschrift für Arafa Mustafa, ed. A. Drost-Abgarjan et al., (Halle, 2008), 93-111. O. El-Daly, Egyptology: The Missing Millennium. Ancient Egypt in Medieval Arabic Writings, (London, 2005) is interested in the factual material that can be derived from Arabic sources. D. Gril, 'Le personage coranique de Pharaon après l'interprétation d'Ibn 'Arabī', Annales Islamologiques, 14 (1978), 37-57 deals with the role of the pharaoh in mystical Quranic exegesis. Cf. also M. Cook, 'Pharaonic History in Medieval Egypt', Studia Islamica, 57 (1983), 67-103 and 
References to pre-Islamic rulers and events played an important role in pre-modern Arabic historiography. The pharaoh, as much as figures such as the Biblical prophets or Alexander the Great, had a number of different functions in these texts. ${ }^{13}$ The respective anecdotes were underpinned by a plurality of meanings similar to the diversity of meanings in treatises on the pharaonic past or the spiritual use of pharaonica. The pharaoh appeared, for example, in statements that dispraised Egypt, that is to say, as a kind of anti-fad $\bar{a}^{\supset} i l$ material: governors sent to Egypt wonder how the pharaoh could have been proud to rule such poor lands and a Basrian underlines that while the Egyptians have turned into pharaohs, the inhabitants of his hometown Basra have remained humble believers, although they have to gain their living in harsh conditions. ${ }^{14}$

The second function of the pharaoh anecdote was its role as a boundary marker between respective insider and outsider groups. By drawing on the negative characteristics of the pharaonic figure, authors assimilated the distant 'Otherness' of ancient Egypt to the more immediate Otherness of groups contemporary to them. ${ }^{15}$ Typical examples of this are the Latin crusaders and the Fatimids in Sunni texts. The term 'pharaoh' was applied to the crusaders in general, ${ }^{16}$ but sometimes specific individuals were designated in this way. John of Brienne (d. 1237), the regent of Queen Yolande of the Kingdom of

C. Cannuyer, 'L'intérêt pour l'Egypte pharaonique à l'époque fatimide. Etude sur L'abrégé des merveilles (Mukhtașar al- $\left.{ }^{c} a j \bar{a}^{\supset} i b\right)$ ', in L'Egypte fatimide: son art et son histoire. Actes du colloque organisé à Paris, mai 1998, ed. M. Barrucand (Paris, 1999), 483-96.

13 On this, see R. Mottahedeh, 'Some Islamic Views of the Pre-Islamic Past', Harvard Middle Eastern and Islamic Review, (1994) 117-26 and more specifically H. Yücesoy, 'Ancient Imperial Heritage and Islamic Universal Historiography: Al-Dīnawarī’s Secular Perspective', Journal of Global History, 2 (2007), 135-55.

14 Ibn Kathīr, Bidāya, X, 316; Muḥammad b. Aḥmad al-Dhahabī (d. 748/1348), Siyar al-a clām al-nubalä ${ }^{\supset}, 25$ vols, eds. Shu ${ }^{c}$ ayb al-Arnā̄ūt et al., (Beirut, 1981-8), IV, 89/90.

15 It has been recently argued that the Quranic pharaoh was less an Egyptian and more a Mesopotamian figure, see A. Silverstein, 'The Qur'anic Pharaoh', forthcoming. However, in the texts under consideration here, the pharaoh had already been clearly placed in Egypt.

16 Mūsā b. Muḥammad Al-Yūnīn̄i (d. 726/1326), Dhayl mir āàt al-zamān, 4 vols., ed. n.n., (Hyderabad, 1954-61), IV, 243 quoting from a letter after the fall of Crusader al-Marqab/Margat in 684/1285. 
Jerusalem in Acre, for instance, is called the 'Pharaoh of ${ }^{\mathrm{c}} \mathrm{Akka \overline {a }} \cdot{ }^{17}$ In fictional letters, the crusaders are depicted as using the term themselves, such as Richard I of England in his negotiations with Saladin for a truce during the Third Crusade. Here, he is cited as having stated that he does not want to be the pharaoh who rules the earth and destroys his own people, as much as Saladin certainly would not want to be the pharaoh of his people. ${ }^{18}$ The locus classicus for the link between crusaders and the pharaoh was Emperor Frederick I Barbarossa's death in 1190 by drowning in the river Göksu in Anatolia, which was inevitably linked to the pharaoh's drowning in the Red Sea while pursuing Moses. ${ }^{19}$

The second Other of Sunni authors, the Fatimids, were assimilated in the same vein to the ancient Egyptian period. Here, two narrative formulae are employed to establish the link. On the one hand, we have Saladin-Yūsuf b. Ayyūb Șalāh al-Dīn-who confronted the Fatimid caliph in Egypt just as the Quranic Yūsuf/Joseph had done with the pharaoh. ${ }^{20}$ Indeed, panegyric poetry replays this theme over and over again. On the other hand, we have the fifth/eleventh-century Fatimid caliph, al-Hākim, who is described as the worst ruler in Egypt since the pharaoh, especially as he supposedly claimed, just as the pharaoh had, divine status. ${ }^{21}$ Akin to this function of the pharaoh as a boundary

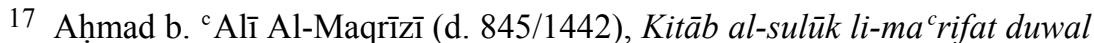
al-mulūk, 4 vols., eds. M. Muṣtafā al-Ziyāda et al., (Cairo, 1934-73), I, 209.

18 Yūsuf b. Rāfíc Ibn Shaddād, (d. 632/1234), Al-Nawādir al-sulțānīya wa-lmaḥāsin al-Yūsufìya, ed. J. al-Shayyāl (Cairo, 1964), 219.

19 For example ${ }^{\mathrm{c}}$ Abd al-Raḥmān b. Ismā̄ $\overline{\mathrm{c}}^{1} \mathrm{l}$ Abū Shāma (d. 665/1267), Kitāb al-rawḍatayn fì akhbār al-dawlatayn al-Nūrīya wa-al-Șalāḥ̄ya, 5 vols., ed. Ibrāhīm al-Zībaq (Beirut, 1997), IV, 193; Muḥammad b. Aḥmad al-Dhahabī (d. 748/1348), Ta ${ }^{\supset}$ rìkh al-Islām wa-wafayāt al-mashāhīr wa-l-a lām, 52 vols., ed. ${ }^{c}$ U. ${ }^{\mathrm{A}}$ Abd al-Salām Tadmurī, (Beirut, 1987-2000), vol. 581-90, 61; Ibn Kathīr, Bidāya, XII, 363.

20 For example, Ibn Kathīr, Bidāya, XII, 283. Ibn Shaddād, Nawādir, 44 (taken over by Abū Shāma, Raw datayn, II, 148-53 and Muhammad b. Sālim Ibn Wāṣil (d. 697/1298), Mufarrij al-kurūb fì akhbār banī Ayyūb, 6 vols, eds. J. alShayyāl, H. al-Rabī' and S. ' Āshūr, vols. 1-5, (Cairo 1953-77), vol. 6 ed. ${ }^{\mathrm{c}} \mathrm{U}$. Tadmurī, (Beirut, 2004), I, 185-8), merely compares Saladin's coming to Egypt with the Quranic Yūsuf, but does not mention the Pharaoh explicitly. This restraint is closer to the original text as the Qur ${ }^{\circ} \bar{a}$ does not explicitly mention the Pharaoh in the Yūsuf sūra, but merely refers to a king ('malik'), on this, see A. Silverstein, 'The Qur'anic Pharaoh' (forthcoming).

21 For example, Abū Bakr b. ' Abd Allāh Ibn al-Dawādārī (fl. 736/1335), Kanz al-durar wa-jāmic al-ghurar, 9 vols., eds. H. Römer et al., (Cairo et al., 
marker for the present is his role in constructing the pre-Islamic Jähilīya as the inversion of the Islamic period. Here we find descriptions of those fighting the developing Islamic community, such as ${ }^{\mathrm{c}} \mathrm{Amr} \mathrm{b}$. Hishām Abu Jahl, who was killed in the battle of Badr, as the 'pharaoh of this community'.22

The third function of the pharaoh was his role as the standard metaphor and simile in order to criticise the unjust and haughty ruler or leading official. This phenomenon was so widespread that it does not require a detailed discussion in the framework of the present study. Among those described to be the pharaoh (or like the pharaoh) were the usual suspects: the Umayyad dynasty, the rule of which is compared to the pharaohs' rule in Egypt; ${ }^{23}$ specific Umayyad caliphs, such as $\mathrm{Mu}^{\mathrm{c}} \overline{\mathrm{a}}$ wiya (d. 60/680), who acted towards the Prophet's family just as the pharaoh had acted towards the Children of Israel; ${ }^{24}$ and al-Walīd II (d. 126/744), who was worse to his people than the pharaoh had been to his subjects. ${ }^{25}$ Alongside these, we find other historical figures, such as the 'rival' caliph, 'Abd Allāh Ibn Zubayr (d. 73/692), who even did to the Prophet's family that which 'the pharaoh had never done to the noble sons of the Children of Israel', ${ }^{26}$ the third/ninth-century ${ }^{~}$ Abbāsid rebel general Șālih b. Wașiff (d. 256/869), who is addressed by the populace as

1960-94), VI, 259 and Jalāl al-Dīn al-Suyūṭī (d. 911/1505), Husn al-muhāọara, 2 vols in one, ed. n.n. (Cairo, 1327/1909), II, 13. On the depiction of al-Hākim in Mamlūk historiography, see N. Haider, 'On Lunatics and Loving Sons: A Textual Study of the Mamlūk Treatment of al-Hākim', Journal of the Royal Asiatic Society, 18 (2008), 109-39.

22 cAbd al-Raḥmān b. ${ }^{\mathrm{c}}$ Alī Ibn al-Jawzī (d. 597/1200), Al-Muntazam fì ta rīkh al-mulūk wa-l-umam, 18 vols, eds. Mușțafā ${ }^{\mathrm{c}} \mathrm{A}$. ${ }^{\mathrm{c}} \mathrm{Ațā} / \mathrm{Muḥammad}{ }^{\mathrm{c}} \mathrm{A}$. cAțā (Beirut, 1992), III, 19ff.

23 Al-Dhahabī, Siyar, III, 143: ${ }^{\mathrm{c}} \overline{\mathrm{A}}^{\circ}$ isha comments on fact the that an Umayyad contender was allowed to compete with one of the Prophet's companions for the Caliphate with the words that this is God's will who even allowed the pharaohs to rule for 400 years in Egypt. Muhammad b. Jarīr alȚabarī (d. 310/923), Ta rīkh al-rusul wa-l-mulūk, 13 vols, ed. Șidqī Jamīl al${ }^{\mathrm{c} A t t ̦ a ̄ r}$ (Beirut, 1998), VII, 134 and ${ }^{\mathrm{c}}$ Alī b. Muhammad Ibn al-Athīr (d. 630/1233), Al-Kāmil fi-l-ta rīkh, ed. C. J. Tornberg (Beirut, 1965-7, reprint of 1851-71 edition with corrections and new pagination), IV, 266/7: Muș ab b. alZubayr (d. 72/691) points to Syria when mentioning the pharaoh in a sermon that he preached in Basra.

24 Ibn al-Dawādārī, Kanz, IV, 64. The speaker is Arwā bt. al-Hāāith.

25 Al-Dhahabī, Siyar, V, 371.

26 Al-Ṭabarī, Ta ${ }^{\circ}{ }^{2} k h$, ed. al- ${ }^{\mathrm{c}}$ Atțāar, VII, 131. 
'O Pharaoh'; ${ }^{27}$ Ibn al-Alqamī, the wazìr who supposedly facilitated the Mongol conquest of Baghdad in 656/1258 and who will suffer the same agony as the pharaoh in the Hereafter; ${ }^{28}$ and the eponym of the wicked Mamlūk administrator, the eighth/fourteenth-century officer, Shams alDīn al-Nashw, who is described as the 'pharaoh' in poems celebrating his dismissal. ${ }^{29}$

However, it is worth underlining that the pharaoh could also appear in anecdotes with a satirical character, potentially undermining the image of the haughty and unjust ruler or official. The Umayyad governor al-Hajjajj b. Yūsuf al-Thaqafĩ (d. 95/714), for example, is linked to this classical negative image of the pharaoh by an account that involves a female Kharijite prisoner. When this prisoner is brought to court, his advisors urge him to execute her. Thereupon, she comments that even the pharaoh's advisors were more pious than al-Hajjāj's men as they had at least advised the ruler to spare Moses. ${ }^{30}$ The same story appears also in a slightly reworked fashion that refrains from merely reproducing the classical use of the pharaoh as the principal metaphor for the haughty and unjust official. In this version, al-Hajjāj is so delighted by the prisoner's answer that he breaks into laughter and releases her. ${ }^{31} \mathrm{~A}$ similar pattern is found in another group of anecdotes that has al-Hajjāj in the same historical context, i.e. in the year 83/702 after suppressing the Kharijite rebellion in Iraq. Here, al-Hajjāj requires all Kharijite prisoners to choose between confessing their previous unbelief or face execution. When a further prisoner is brought to him, al-Hajjāj states that he will probably not testify against himself. The prisoner answers that, on the contrary, he is the most unbelieving person on earth, even more of an unbeliever than the pharaoh - an answer that earns him his release by

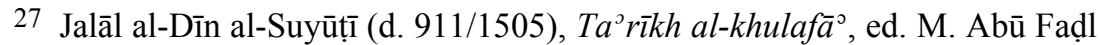
Ibrāhīm, (Cairo, 1976), 577/8.

28 Ibn al-Dawādārī, Kanz, VIII, 36.

29 Al-Maqrīīin, Sulūk, II, 479. On al-Nashw, see A. Levanoni, 'The AlNashw Episode: A Case Study of "Moral Economy", Mamlūk Studies Review, 9/1 (2005), 207-219.

30 Ahmad b. Muhammad Ibn ${ }^{\mathrm{c}}$ Abd Rabbih (d. 328/940), Al- ${ }^{\mathrm{c}}$ Iqd al-farìd, 9 vols, eds. Mufìd Muḥammad Qumayḥa et al., 3rd edn (Beirut, 1983), I, 55; Aḥmad b. Muḥammad Ibn Khallikān, (d. 681/1282), Wafayāt al-a $a^{c} y \bar{a} n$ wa$a b n \bar{a}^{\supset}$ al-zamān, 8 vols, ed. I. 'Abbās, (Beirut,1968-72; repr. Beirut 1994), II, 37.

31 Ibn ${ }^{\mathrm{c}} \mathrm{Abd}$ Rabbih, ${ }^{c} I q d$, II, 48. 
the delighted governor. ${ }^{32}$ Thus, in both cases the construction of the stereotypical image of the unjust official is fractured by the satirical element and the subsequent forbearance of the governor.

The 'speak to him gently' anecdote

Besides the anecdotes that mainly served to criticise office holders, there exists a stream of pharaoh anecdotes that characterise rulers and officials in more complex and contradictory ways. The most salient of these is the 'speak to him gently' anecdote. This appears in two different versions that will be called in the following 'original' and 'secondary'. The original version runs thus: a religious man (generally an ascetic) meets a ruler; the religious man admonishes the ruler in harsh words, and the ruler rebukes the religious man with reference to the Quranic verse 20:44 'speak to him gently, perhaps he will take heed or show fear'. With these words, which were God's advice to Moses and Aaron when He sent them to the pharaoh, the ruler mirrors the improper behaviour of the religious man. The religious man repents as he understands that even the pharaoh had the right to be addressed in a gentle manner and the ruler forgives him. It is in al-Țabarı̄'s chronicle that we find the archetype of this original version where al-Rashīd is the ruler and the religious man an ascetic who remains anonymous. The original version continued to be transmitted in subsequent works, either with reference to al-Rashīd or to other rulers, most importantly, al-Ma ${ }^{\circ}$ mun. The anecdote was also changed in other regards, for instance the ascetic was identified with a name or replaced by a scholar, but its narrative structure was substantially unchanged.

The secondary version, in contrast, considerably alters the narrative pattern of the anecdote. Such changes include minor modifications, for example that the religious man and the ruler do not meet in person, but via written correspondence. However, these changes include also amendments that touch upon the central message of the anecdote, for example that it is not the religious man, but the ruler who has to repent. Such secondary versions gained in importance in texts that were written in the Middle Period (c. 1000 to 1500AD). Occasionally, the link to the original version seems to be weak, but all of these versions have two characteristics in common: the Quranic verse 20:44 is the crucial element, and a religious man confronts a ruler or official.

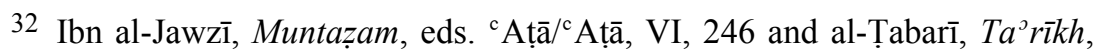
ed. al- ${ }^{\mathrm{c}}$ Atțār, VII, 303. 
The rulers and officials that are inserted into the two versions stretch from the above-mentioned 'rival' caliph, Ibn al-Zubayr (d. 73/692) via the ${ }^{\mathrm{c}}$ Abbāsid Caliphs Hārūn al-Rashīd (d. 193/809) and al-Ma ${ }^{\circ}$ mūn (d. 218/833) to the seventh/thirteenth-century Rasūlid ruler of Yemen alMalik al-Muca aẓzam Yūsuf (r. 647/1250-694/1295), the Mamlūk Sultān Muhammad b. Qalāwūn (r. with interruptions 693/1293-741/1341) and the early eighth/fourteenth-century Mamlūk officer Quṭlūbak al-Manșurī (d. 716/1316-7). We find the 'speak to him gently' anecdote in its different versions in a number of works (universal chronicles, local chronicles, biographical dictionaries, and adab works), such as alTabarī's (d. 310/923) Ta rīkh, Ibn 'Abd Rabbih's (d. 328/940) al- ${ }^{c} I q d$ al-farìd, Ibn al-Jawzī’s (d. 597/1200) al-Muntazam, al-Yāfi ${ }^{c}{ }^{\prime}$ 's (d. 768/1367) Mir āat al-jinān, al-Maqrīzī’s (d. 845/1442) al-Sulūk and Ibn Hajar's (d. 852/1449) al-Durar. ${ }^{33}$

\section{The 'original' al-Rashīd/al-Ma'mūn version}

Al-Țabarî's archetype is not only the earliest, but also the most detailed and elaborated variant that we have of the original version. His anecdote, which has al-Rashīd as the ruler, introduces the central element, the comparison with the Quranic pharaoh, in considerable length:

A certain person has mentioned that he was with al-Rashīd at al-Raqqa after he had set out from Baghdad. He went out hunting with al-Rashīd one day, when an ascetic appeared before him and addressed him, 'O Hārūn, fear God!' The caliph said to [the official] Ibrāhīm b. ' Uthmān b. Nahīk, 'Take this man with you, until I get back.' When he returned, he called for his midday meal. Then he gave orders for the man to be fed with the choices of his food. When he had eaten and drunk, he summoned him and said, 'O fellow, treat me fairly when you deliver your sermons and make your intercessions!' The man replied, 'That is the least which is due to you.' The caliph said, 'Then tell me, who is more evil and wicked, me or the pharaoh?' The ascetic replied, 'Without doubt the pharaoh, because he said 'I am your Lord, the Most High,' [Qur'ān, 79:24] and 'I know no god

33 Al-Ṭabarī, Ta ${ }^{j}$ ìkh, ed. al- ${ }^{\mathrm{c}}$ Atțāar, V, 129; Ibn ${ }^{\mathrm{c}}$ Abd Rabbih, ${ }^{c} I q d$, I, 54/5; II, 235/6; III, 110; ' Abd al-Raḥmān b. ${ }^{\mathrm{c}}$ Alī Ibn al-Jawzī, Al-Muntaẓam fì tawārīkh al-mulūk wa-l-umam, 13 vols, ed. Suhayl Zakkār (Beirut, 1995-6), V, 370; ' Abd Allāh b. As ${ }^{\mathrm{c}}$ ad al-Yāfic ${ }^{\mathrm{c}} \overline{1}$ (d. 768/1367), Mir ${ }^{\mathrm{j}} \bar{a}$ al-jinān wa- ${ }^{c}$ ibrat alyaqzā̄n, 4 vols, ed. Khalīl al-Manșūr (Beirut, 1997), II, 55; al-Maqrīzī, Sulūk, II/1, 135/6; Aḥmad b. ' Alī Ibn Hajar al- ${ }^{c}$ Asqalānī (d. 852/1449), Al-Durar alkāmina fì a $a^{c}$ ān al-mi a al-thāmina, 5 vols., ed. Muhammad Sayyid Jād alHaqq (Cairo, 1966-67), III, 337/8. 
for you except myself' ${ }^{34}$ [Qur`ān, 28:38]' The Caliph said, 'You have spoken truly; now tell me, who is better, you yourself or Moses, son of 'Imrān?' He replied, 'Moses is the one who spoke with God and was his chosen one, whom He took as his protégé and upon whom he relied for delivering His inspired revelations, and He singled him out to speak with Him out of all His creation.' The caliph said, 'You have spoken truly; are you not aware that when He sent Moses and his brother to Pharaoh, He said to them, 'Speak to him gently, perhaps he will take heed or show fear' [Qur'ān, 20:44]. The Quranic commentators have mentioned that $\mathrm{He}$ ordered the two of them to call the pharaoh by his patronymic [i.e. his kunya], this (daring move) being done when pharaoh was in his status of arrogance and overweening pride, as you have well known. Yet you come to me at a moment when I am in this position of which you are aware! I fulfil the greater part of the prescriptions which God has imposed upon me as obligatory, and I worship none but Him. I obey the most important of the limits against transgression laid down by God, His commands and His prohibitions. But you have harangued me with the most violent and unseemly words, and the roughest and foulest of speech; you have not been schooled in the practice of God's praiseworthy discipline nor have you adopted the good qualities of the righteous ones! So what has been making you feel confident that I shall not come down heavily upon you? If this last is in fact the case, you will have laid yourself open to what was a quite unnecessary risk!' The ascetic replied, 'I have made a mistake, O Commander of the Faithful, and I ask your pardon.' He replied, 'God has already pardoned you,' and ordered him to be given twenty thousand dirhams. However, the ascetic refused to accept them and said, 'I don't need the money at all, I am an ascetic who wanders round.' [The general] Harthama spoke to him and looked at him askance, 'You boorish fellow, are you hurling back the Commander of the Faithful's present in his face?' But al-Rashīd said, 'Leave him alone,' and then told the ascetic, 'We didn't offer you the money because you are in need of it, but simply because it is our custom that no one who is neither one of the caliph's entourage nor one of his enemies ever addresses him without the caliph giving him a present and rewarding him. So accept what proportion you like of our gift, and spend it how you please!' The man took two thousand dirhams from the

34 C. E. Bosworth, The History of al-Tabari. The 'Abbasid Caliphate in Equilibrium, 40 vols (New York, 1989), XXX, 324 misreads this passage as: 'The caliph said, 'Tell me now, am I an evil and most wicked person, or a pharaoh?' The ascetic replied, 'Nay, a pharaoh'. The caliph quoted, 'I am your Lord the Most High', and the man responded, 'I am your Lord, the Most High' [Qur’ān, 79:24] and 'I know no god for you except myself'.' 
sum of money and divided it out among the doorkeepers and those present at the court. ${ }^{35}$

Before discussing variants of this original version, it has to be underlined that the 'speak to him gently' anecdote is closely linked to another anecdote that plays a salient role in the historiography of the early 'Abbāsid caliphate, namely the 'scholar meets ruler' stories. The initial setting of these 'scholar meets ruler' anecdotes is similar: the scholar encounters also a ruler and admonishes him. The difference is that in these anecdotes the ruler breaks into tears, a courtier rebukes the scholar, the scholar ignores him, intensifies his preaching, and finally the unsettled ruler offers a gift that is inevitably rejected by the scholar.

It has been shown that this 'scholar meets ruler' anecdote was one of the standard items in Abbāsid historiography in order to idealise alRashîd as the model of Islamic rulership - especially in later medieval Islamic political theory that saw the caliph's main role as being restricted to leading the community in the religious rituals and defending it in times of war. Al-Rashīd's reign was the preferred place of remembrance for the ascription of later mainstream positions as it preceded the period of civil war and the mihna under his successors. In this sense, his rule served as a point of convergence in order to rebut, for example, pro$\mathrm{Mu}^{\mathrm{c}}$ tazilite positions. ${ }^{36}$ The 'scholar meets ruler' anecdote was functional in underlining that the exemplary ruler showed deference to the principles agreed upon by the scholarly elite and admired spiritual figures of high status.

One variant of these anecdotes also includes a reference to the pharaoh. When al-Rashīd encounters the ascetic Fuḍayl b. 'Iyād (d. 187/803) during one of his nocturnal tours of Baghdad, Ibn 'Iyāḍ admonishes him and warns of the Day of Judgement. Al-Rashīd bursts into tears and in the end says to his wazì in desperation, 'He has not made you Hāmān [the pharaoh's counsellor in the Qur`ān] without making me pharaoh' ${ }^{37}$ The 'scholar meets ruler' anecdote is closely linked to the issue of commanding right and forbidding wrong, that is the individual's duty to intervene when another is acting wrongly. Cook has shown in his monograph on this issue that the pharaoh is one of the

35 Al-Ṭabarī, Ta ${ }^{\top} r \bar{k} k h$, ed. al- ${ }^{\mathrm{c}}$ Atțār, X, 129; translation based on Bosworth (1989), 324/5.

36 El-Hibri, Reinterpreting Islamic Historiography, 19-31.

37 (Attributed to) Muhammad al-Ghazālī (d. 505/1111), Tibr al-masbūk fì nașịhat al-mulūk, ed. M. Aḥmad Damaj (Beirut, 1987), 120-2. 
figures that reoccurs in discussions in this regard. Sufyān al-Thawrī, 'a compulsive forbidder of wrong', for instance compares in a confrontation the wazìr of the Caliph al-Manșūr (d. 158/775) to the pharaoh. In the same sense, in views attributed to Mālik b. Anas (whom we will encounter in the following again) on the question of forbidding wrong references to the pharaonic example are included. ${ }^{38}$

In contrast to the 'scholar meets ruler' anecdote, the 'speak to him gently' anecdotes reverse this pattern of interaction and ends with the religious man repenting and the ruler having the upper hand in moral terms. However, the interaction between ruler and ascetic in this anecdote - and most importantly the final repentance of the asceticshould not be seen as a counterpart to the 'scholar meets ruler' narratives in which the ruler repents, but rather the two anecdotes complement each other. The 'speak to him gently' narrative was primarily used to show that the right for criticising the ruler and for commanding right and forbidding wrong was reserved to those who were qualified: the religious scholars and outstanding pious men. In contrast, other disapproving religious observers, such as the anonymous ascetic in al-Ṭabarî's archetypal version, were not entitled to this right. Non-scholars had to abide by the caliph's rule and accept his leadership; the ruler had the right and the duty to show such persons their limits. ${ }^{39}$ This line of thought is expressed by al-Rashīd's words to the ascetic, 'you have not been schooled in the practice of God's praiseworthy discipline nor have you adopted the good qualities of the righteous ones!' That is to say, an explicit statement that the ascetic's criticism of the ruler is not inappropriate per se, but because it is raised by somebody who is not entitled to do so. Concomitantly, the individual who scolds the ruler in the 'scholar meets ruler' anecdotes is always a qualified scholar.

As the 'speak to him gently' anecdote with al-Rashīd touched upon this central issue, that is the religious men's entitlement to criticise the ruler, it is not surprising that it reappeared in other Arabic historiographical and adab texts. The interesting aspect of these variations of the original versions are the changes that were made to the anecdote's form and meaning. These changes can be discussed by taking into consideration a typical example from both historiography and adab literature. Two important texts in which the original version was taken up and reworked are Ibn al-Jawzî’s universal chronicle and Ibn ${ }^{\mathrm{c}} \mathrm{Abd}$

38 M. Cook, Commanding Right and Forbidding Wrong in Islamic Thought (Cambridge, 2000) 65 and 358-60.

39 El-Hibri, Reinterpreting Islamic Historiography, 30-31. 
Rabbih's adab work. Although they were authored within different fields of knowledge, it is apparent that these two texts were underpinned by the same narrative strategies that are typical for the process of transmitting the 'speak to him gently' anecdote. First, authors increasingly tended to summarise the anecdote. Generally, they only mentioned the Quranic citation without going into more detail. Once the framework of the anecdote had become established with the original version, later authors arguably saw no further need to go into the same depth. Second, authors tended to rework the factual material. On the one hand, factual elements, such as the geographical setting, al-Raqqa, and the name of the official, Ibrāhīm b. Nahīk could simply disappear. On the other hand, such material could be significantly altered, for example by replacing alRashīd with al-Ma ${ }^{\circ}$ ūn, and by turning the ascetic into a scholar. Finally, the meaning of the anecdote began to be reinterpreted as the central issue of al-TTabarî's version, the right to criticise the ruler, diminishes in importance. In other words, authors were engaged in a process of summarising the text, reworking the factual material, and reinterpreting the meaning while staying faithful to the outline of the original version. In Ibn al-Jawzî̀s universal chronicle we find the following account:

One day an ascetic came to Hārūn al-Rashīd and said, 'O Hārūn, fear God!' Hārūn al-Rashīd withdrew with him and said, 'O fellow, treat me fairly. Who is more evil, me or the pharaoh?' The ascetic replied, 'Without doubt the pharaoh.' Hārūn al-Rashīd continued, 'Then who is better, you yourself or Moses?' He replied, 'Without doubt Moses.' Hārūn al-Rashīd said, 'Are you not aware that when He sent Moses and his brother to him [i.e. the pharaoh], He said to them, 'Speak to him gently', but you have harangued me with the most violent and unseemly words, you have not been schooled in the practice of God's praiseworthy discipline nor have you adopted the good qualities of the righteous ones!' The ascetic replied, 'I ask God for forgiveness.' He replied, 'God has already pardoned you' and ordered him to be given twenty thousand dirhams. However, the ascetic refused to accept it. These are the right manners. ${ }^{40}$

Compared to al-Ṭabarì's version, the anecdote here is significantly summarised and several elements have disappeared, such as the original setting that had the ruler on the hunt near al-Raqqa, the timing after the midday meal and the role of other persons such as the above-mentioned Ibrāhīm b. ' Uthmān b. Nahīk and Harthama. In addition, the author

40 Ibn al-Jawzī, Muntazam, ed. Zakkār, V, 370. 
introduces the Quranic citation rather briefly and gives less prominence to the exchange between the ascetic and al-Rashīd. Most importantly, the central message of the pharaonic reference is now different. While the framework is still the confrontation between the ruler and religious men, the inappropriate behaviour of the ascetic does not play such a key role anymore. On the contrary, Ibn al-Jawzi explicitly decides to intervene in the narrative with his final comment in order to praise the ascetic for refusing to take the caliph's money. This shifts the focus of the anecdote away from the issue of legitimate criticism towards another classical question in Islamic scholarship, namely how religious scholars and ascetics should frame their relationships with rulers. By excluding the final element of the original version that had the ascetic taking some of the ruler's money, Ibn al-Jawzī clearly expressed his vision of 'the right manners', i.e. the distance between the religious man and the worldly ruler.

Ibn ${ }^{\mathrm{c}} \mathrm{Abd}$ Rabbih included two versions of the anecdote into his $a d a b$ encyclopaedia. The first is a very condensed version of the original anecdote that is of no great concern for the discussion. ${ }^{41}$ However, his second version is of interest as it shows how the original structure of the anecdote could be reworked more substantially:

Al-Hārith b. Miskīn called upon al-Ma ${ }^{3}$ mūn who asked him about some matter. Al-Hārith responded, 'I say about hat what Mālik b. Anas said to your father Hārūn al-Rashīd' and cited his words. Al-Ma ${ }^{\circ}$ mūn was not pleased with his reply and said, 'You responded in a stupid way and so did Mālik.' On this al-Hārith b. Miskīn responded, 'Then the one who listened, O Commander of the Faithful, is more stupid than the two who responded in a stupid way.' The colour of al-Ma ${ }^{\circ}$ mūn's face changed and al-Ḥārith $b$. Miskīn rose and left. He regretted later what he had said. As soon as he was home an envoy of al-Ma ${ }^{\circ}$ mūn came. Al-Hārith expected the worst, put on his shroud and attended upon al-Ma ${ }^{\mathrm{D}}$ mūn. Al-Ma ${ }^{\mathrm{T}}$ mūn asked him to come close, stared at him and said, 'O You, God had ordered somebody better than you to employ gentle words to somebody worse than me when $\mathrm{He}$ ordered the Prophet Moses to go to the pharaoh, 'Speak to him gently, perhaps he will take heed or show fear'. Al-Ḥārith responded, 'O Commander of the Faithful, I admit my sin and ask the lord for

41 Ibn ${ }^{\mathrm{c}}$ Abd Rabbih, ${ }^{c} I q d$, III, 110: 'A man said to al-Rashīd, 'O commander of the Faithful! I want to admonish you with a sermon that contains some rudeness, so endure it!' Al-Rashīd said, 'Nay, God ordered somebody better than you to employ gentle words to somebody more wicked than me. He said to His Prophet Moses when he sent him to the pharaoh, 'Speak to him gently, perhaps he will take heed or show fear.', 
forgiveness.' Al-Ma ${ }^{3}$ mun replied, 'May God forgive you, leave if you want'. 42

The first two of the aforesaid narrative strategies, summarising the text and reworking the factual material, are clearly apparent, especially with the change from al-Rashīd to al-Ma ${ }^{3}$ mun. Of greater interest is the third strategy, the reinterpretation of the anecdote's meaning. The author set this anecdote into his section on 'The sultān's forbearance with people of religion and virtue on their being audacious with him' which is part of the Kitāb al-Sultān (Book of Governance). The aim of this section is to praise rulers for their forbearance, here al-Ma ${ }^{5}$ mūn's forbearance vis-àvis al-Hārith who was exiled or imprisoned in other anecdotes that show confrontations between al-Ma ${ }^{\circ}$ ūn and him. ${ }^{43}$ In this sense the anecdote's meaning was changed from an emphasis on the entitlement of outstanding religious men to address the ruler in harsh terms, to a focus on an exemplary trait of rulership: forbearance. The question is not so much whether or under which conditions the ruler might be criticised, but rather the way the ruler should deal with his subjects.

Ibn ${ }^{\mathrm{c}} \mathrm{Abd}$ Rabbih changed the story in other regards that were arguably caused by his decision to insert al-Ma ${ }^{\circ}$ mun as protagonist. The appearance of the scholar, not an ascetic, can also be read as a reference to al-Ma ${ }^{\circ}$ mūn's somewhat strained relations with religious scholars, especially within the framework of the mihna. This turbulent relation perhaps also explains the ruler's rude behaviour in the anecdote, especially the use of the term 'stupid' (laqad tayyasta). The explicit comparison to al-Rashīd that the scholar introduces in the very beginning of Ibn 'Abd Rabbih's version is hereby substantiated. In contrast to alRashīd's calm and composed reaction, al-Ma ${ }^{\circ}$ mun appears in the beginning uncontrolled in his interaction with a scholar - and fails even to offer a gift in the end. Ibn al-Jawzī, on the contrary, did not delve into the issues surrounding the mihna, and consequently saw no need to exchange the ascetic with a scholar.

It was quite crucial for Ibn al-Jawzī that the religious man was an ascetic. His main concern was to express his deeply held conviction that one should keep one's distance from the rulers. To this end, the ascetic was much more appropriate a figure than the religious scholar of Ibn ${ }^{\mathrm{c}}$ Abd Rabbih. The question arises: why did Ibn al-Jawzī and Ibn ${ }^{\mathrm{c}} \mathrm{Abd}$ Rabbih decide to include the anecdote in the first place - a decision that

42 Ibn ${ }^{\mathrm{c}}$ Abd Rabbih, ${ }^{c} I q d$, I, 54/5.

43 See, for example, al-Dhahabī, Siyar, XII, 56. 
is noteworthy in itself as many other authors of historical and adab works did not report it? The preceding discussion has shown that factuality was a secondary concern for these authors who considerably summarised the text, and significantly changed the factual material. Rather, it can be argued that the authors included the anecdote primarily because they could express, with the reworked versions, concerns that were of relevance to their outlooks, namely the acceptable closeness of scholars to rulers and characteristics of good rulership. Consequently, they changed al-Tabarî's 'speak to him gently' anecdote with regard to its form and with regard to its meaning. In the next section, the discussion will turn to authors who decided to include the anecdote in its secondary version. The argument of this section will be extended in the sense that it will explore how far both the act of inclusion and the narrative strategies can be understood within the 'social logic' 44 of the specific text.

Secondary versions of 'speak to him gently' anecdotes: beyond al-Rashìd and al-Ma ${ }^{3} m \bar{u}$

In the 'secondary' versions, which gained in importance during the Middle Period, the authors changed central features of the anecdote to such a degree that it became hardly recognisable. The only common features that remained were the 'speak to him gently' element as well as the question of the relationship between a scholar/religious man on the one hand, and a ruler/official on the other. Although the secondary versions seem at times quite remote from the original version, the authors underlined that they considered their variant to be connected with it.

This is, for example, apparent in the chronicle of al-Yāfici ${ }^{c}$ (d. 768/1367) who inserted into the anecdote the seventh/thirteenth-century Yemeni chief judge and the Yemeni Rasūlid ruler (r. 647/1250$694 / 1295$ ) as the two main protagonists. The link to the original version seems, at first glance, weak:

The great scholar, the reputed friend of God, leader of the two groups, venue of the two ways Ismāc $\overline{1} l b$. Muhammad al-Hadramī - may God bless his soul—wrote to the ruler of Yemen, [Yūsuf] al-Malik al-Muzaffar on a

44 The term is borrowed from G. Spiegel who employs it in order to describe the combination of narrative analysis and social context. See, G. M. Spiegel, The Past as Text. The Theory and Practice of Medieval Historiography (Baltimore and London, 1997). 
potsherd, ${ }^{45}$ 'O Yūsuf!' Thereupon al-Muẓaffar wrote to him and scolded him, 'God sent somebody better than you to somebody more wicked than me.' According to a [further] line of transmission [it is reported that the ruler wrote], 'Imagine that you would be Moses - and you are not Mosesand that I would be the pharaoh - and I am not the pharaoh. God said, 'Speak to him gently!" 46

Due to the faint resemblance with the original al-Rashīd version, the author explicitly introduced the link to it in the preceding lines. Here, he cited the original report, although with some considerable changes and additions in the factual detail:

Al-Așmac ${ }^{c}$ [d. 213/828] reported, 'While al-Rashīd and I were in Makka, al- ${ }^{-} \operatorname{Umar}^{-47}$ confronted him and said, 'O Commander of the Faithful! I would like to address you with rude words. Endure it for the sake of God, to whom belong power and majesty.' Al-Rashīd replied, 'I will not endure it! By God, God had sent somebody who was better than you to somebody who was more wicked than me and said, 'Speak to him gently." I [alYăfí ${ }^{i}$ ] said, 'What resembles this report is that what is well known in the Yemen among the scholars and the commoners [on the above exchange between the chief judge and the ruler].'

Thus, al-Yāfi ${ }^{c} \overline{1}$ clearly understood his 'potsherd' anecdote as a variation of the original 'speak to him gently' report. In order to smooth the chronological and factual displacement of the narrative pattern, he relocated the original version with Hārūn al-Rashīd by locating it in the Hijāz, which was obviously of more relevance for his Yemeni chronicle than Syrian al-Raqqa. The author not only had the protagonists meeting at Mecca, but he also identified the anonymous ascetic as al- ${ }^{c}$ Umarī, a well-known saintly figure who dwelled in the Hijāz.

Al-Yāfic $\overline{1}$ 's text is not only of relevance in order to prove that the primary and secondary versions - despite the discrepancies - are variants of one and the same anecdote, and to show that the reworking of the factual material continued also in this later period. Rather, the factual and chronological displacement is again accompanied by a

45 The original 'saqifat khazaf' in the edition is a misreading of shaqaf khazaf as it is also given in the second report of this event in al-Yāfic $\overline{1}$, Mir $^{\top} \bar{a} t$, IV, 35 .

46 Al-Yāfi $\bar{c}^{\overline{1}}, M_{i r}{ }^{\circ} \bar{a} t$, II, 55

47 c Abd Allāh b. ${ }^{\mathrm{c}} \mathrm{Abd}$ al- ${ }^{\mathrm{c}} \mathrm{Az} \overline{\mathrm{i}} \mathrm{z}$ al- ${ }^{\mathrm{c}} \operatorname{Umar} \overline{1}$ (d. 182/798 or 184/800), a noted ascetic and descendant of the Umayyad caliph, ${ }^{\mathrm{c}}$ Umar I. On him cf. al-Tabarī, tr. Bosworth (1989), XXX, 316, n. 1060. 
reinterpretation of the anecdote's meaning. In al-Yāficī's version neither the scholars' right to address the ruler, nor the ruler's forbearance play any further role. The religious man, Ismā ${ }^{c} \overline{1} l$ al-Hadramī, is reduced in both of his versions, the reworked original anecdote and the 'potsherd' anecdote, to a marginal role. Both versions end with the ruler's rebuke and the religious man's loss of agency to such a degree that he cannot even express his repentance. This description of the scholars' submission to the ruler reappears with more clarity when al-Yâfic ${ }^{c} \overline{1}$ narrates the 'potsherd' anecdote a second time in the framework of al-Hadramî's obituary. Here, the author links the anecdote to a report that the ruler had nominated al-Hadiramī to a judgeship. Al-Hadramī was initially unwilling to take up the post, which al-Yăfi ${ }^{c} \overline{1}$ wearily commented with the words, 'But he was the sulțān and what the sulțān ordered happened' ${ }^{48}$ In place of offering a normative message, the author took the decision to employ the anecdote as an example of what he perceived to be a situation where the scholars had submitted to the ruler.

A decisive break in the meaning that was ascribed to this anecdote occurred in the first half of the ninth/fifteenth century. At this point the anecdote's original message was practically inverted: rather than showing the ruler's right to fend off illegitimate criticisms, and discussing characteristics of exemplary rule, it was turned into a narrative pattern that allowed criticism of office holders. This reworking occurs in the works of two near-contemporary historians in the late Mamlūk period: the biographical dictionary of Ibn Hajar al- ${ }^{c}$ Asqalānī and the chronicle of al-Maqrīzī. Ibn Hajar al- ${ }^{c}$ Asqalān̄̄'s reshaped the anecdote with the scholar Ibn Taymiya (d. 728/1328) and the highranking Mamlūk officer Quṭlūbak al-Manșurī (d. 716/1316-7) as new actors. Here, Ibn Taymīya attended to Quṭlūbak who was renowned for his dishonest conduct in commercial affairs and had again failed to satisfy a trader's claim:

It is said that one day Ibn Taymīya came to him [Quṭlūbak] with a trader in order to intercede for the later so that his claim would be fulfilled. Quțulbak said to him, 'When I see the officer at the door of the faqi $r$, [I know that] the officer is blessed and the faqi $r$ is blessed. However, when I see the faqi $r$ at the door of the officer, [I know that] the officer is doomed and the faqīr is doomed.' Ibn Taymīya said to him, 'The pharaoh was worse than you and Moses better than me. Nevertheless, Moses came to his door everyday

48 Al-Yāfic $\overline{1}, M i r^{\jmath} \bar{a} t, \mathrm{IV}, 35$. 
to enjoin him to belief and I enjoin you to pay this man's debts.' Quṭlūbak could not, but obey his order and fulfil the man's claim. ${ }^{49}$

The two main characteristics of the secondary version are still apparent in this narrative: the encounter is between a religious scholar and a representative of political might. Besides which, Ibn Taymīya employs the formula 'worse than you better than me' that featured prominently in the original anecdote and the other secondary versions. However, of more relevance is Ibn Hajar's drastic alteration of the anecdote's meaning. The right to invoke the pharaonic element was now given to the scholar, whereas it had always been the ruler in the preceding versions who had introduced this reference. In contrast to al-

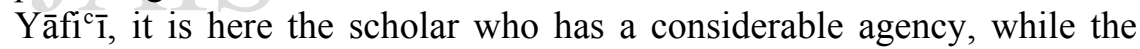
official's role remains passive. It is not the scholar who repents in the end, but the official has to give in and to implicitly acknowledge his misbehaviour. Thus, Ibn Hajar moves the anecdote much closer to the 'scholar meets ruler' stories that stood originally only in a complementary relationship to the 'speak to him gently' anecdote: in his version the official, not the religious man, admits his misbehaviour because his religious man represented those who are entitled to criticise.

The version of Ibn Hajar's contemporary al-Maqrīzī (d. 845/1442) exemplifies the changes to the anecdote and its reinterpretation in this period in a more profiled and nuanced way. Al-Maqrīī's version of the 'speak to him gently' anecdote is found in al-Sulūk, his history of Egypt and Syria. The setting is now the year 714/1314. A group of Copts who were worshipping at the $\mathrm{Mu}^{\mathrm{c}}$ allaqa church in Fustạt had run short of candles, so they borrowed some from the nearby ${ }^{\mathrm{c}} \mathrm{Amr}$ ibn al- ${ }^{\mathrm{c}} \overline{\mathrm{A}} \mathrm{s}$ mosque. This misappropriation of Muslim candles led to protests under the leadership of the $\operatorname{Shāfi~}^{\mathrm{i}} \overline{1}$ jurisprudent Nūr al-Dīn al-Bakrī. ${ }^{50}$ Subsequently, al-Bakrī demanded an audience with the Sulțān Nāṣir alDīn Muhammad b. Qalāwūn as the loan of the candles had been

49 Ibn Hajar, Durar, III, 337/8.

50 Nūr al-Dīn ${ }^{c} A l i ̄$ b. Ya ${ }^{c}$ qūb b. Jibrīl al-Bakrīi, d. 724/1324. On him, see Aḥmad b. ${ }^{\mathrm{c}}$ Abd al-Wahhāb al-Nuwayrī (d. 733/1333), Nihāyat al-arab fì funūn al-adab, 33 vols, (Cairo, 1923-2002), XXXIII, 77; al-Dhahabī, Ta ${ }^{\circ} r \bar{k} k h$, vols 701-46, 216; Khalīl b. Aybak al-Ṣafadī (d. 764/1363), $A^{c} y \bar{a} n$ al- ${ }^{c} a s ̦ r$ wa-a ${ }^{c}$ wān al-nașr, 4 vols, ed. F. Aḥmad al-Bakkūr (Beirut 1998), III, 1293/4; al-Ṣafadī, Al-Wāfi bi-al-wafayāt, 30 vols, ed. Hellmut Ritter et al., (Istanbul et al. 193197), XXII, 331/2; ' Abd al-Wahhāb b. ' Alī al-Subkī (d. 771/1370), Tabaqūt alShāficīya al-kubrāa, 10 vols,, eds. M. Muhammad al-Ṭanāḥī/cAbd al-Fattāh M. al-Ḥilw (Cairo, 1964-76), X, 370/1; Ibn Ḥajar, Durar, III, 214/5. 
authorised by two of his high-ranking officials, who were recent Coptic converts to Islam. This audience was attended by the four chief judges and high-ranking officers:

Then Nūr al-Dīn al-Bakrī addressed the sulțān [Nāṣir al-Dīn Muhammad b. Qalāwūn] in coarse and rough language until the sultạn became furious when al-Bakrī said, 'The best deed is truthful speech in the presence of a tyrannical sultān. You appointed the newly converted Copts and you gave them authority over your State and the Muslims. You illegally diminished the Muslims' possessions and their benefits.' And [he added] more [words] in this regard. The sultạn replied, 'Woe to you, am I tyrannical?' Al-Bakrī said, 'Yes! You gave the Copts control over the Muslims and strengthened their religion.' At these words, the sultān could not restrain himself and took the sword intending to hit him, but the officer Tughay ${ }^{51}$ grabbed his hand. The sulțān turned to the [Mālikī] chief judge Zayn al-Dīn b. Makhlūf and exclaimed, 'O judge, can he dare to be so audacious with me? What am I supposed to do with him? Tell me!' Ibn Makhlüf answered, 'He did not say anything that can be disapproved of and nothing has to be done against him as he merely transmitted a sound hadìth.' The sulțān screamed at him, 'Leave me!' Ibn Makhlūf immediately got up and left. Șadr al-Dīn b. alMuraḥhil—who was present-addressed the Shăfi ${ }^{c} \overline{1}$ chief judge, Badr alDīn Muhammad Ibn Jamāca, 'O lord, this man was audacious with the sultān, but God the exalted ordered Moses and his brother when he sent them to the pharaoh, 'Speak to him gently, perhaps he will take heed or show fear." Ibn Jamāa a told the sultān, 'He was audacious and our lord the sultạn can only show his forgiveness.' The sultạn grew even more furious, rose from his chair and [again] intended to hit al-Bakrī with his sword. Țughay, Arghūn and the other officers rushed on him and waited until he regained his countenance. The sultạn ordered al-Bakrî̀s tongue to be cut off; al-Bakrī was brought to al-Rahiba and thrown to the ground. Țughay advised him to plead for pardon so al-Bakrī started to shout, 'By God's Prophet!' He repeated it several times until the officers had pity with him. Țughay told the officers to intercede with the sultān in favour of al-Bakrī. They all went to the sultạn and pleaded for al-Bakrī until the sulțān decreed his release and his banishment from Egypt. The amīr Aydumur al-Khațīī criticised al-Bakrī for initially having been so bold in addressing the sulțān, but subsequently abasing himself. Al-Bakrī was attacked because his stance

51 Sayf al-Dīn al-Nāṣirī (d. 718/1318) was one of the most influential officers during the reign of Nāșir al-Dīn Muḥammad b. Qalāwūn until he fell into disgrace towards the end of the latter's reign. See, for example, A. Levanoni, A Turning Point in Mamluk History: The Third Reign of al-Nāssir Muhammad Ibn Qalāwūn (1310-1341), (Leiden, 1995), 57/8. 
[of commanding the Right and forbidding the Wrong] was not sincere towards God. ${ }^{52}$

This description of the confrontation at court was included into a number of Mamlūk and Ottoman chronicles and biographical dictionaries that reported the 'candle scandal'. ${ }^{53}$ However, many other authors preferred to exclude the confrontation between ruler and scholar from their narratives. ${ }^{54}$ In addition, those versions that do mention the confrontation at court show among themselves considerable differences in the narrative structure and points of detail. For instance, some include direct speech as an element of dramatisation while others employ mostly indirect speech $^{55}$ and most texts agree that Șadr al-Dīn b. al-Muraḥhil was present and played a central role, while some authors do not mention him at all. ${ }^{56}$

Al-Maqrīzī drew on this diverse material and gave the anecdote a unique form. The most remarkable feature is that al-Maqrīzī was the only author who included the 'speak to him gently' element into the 'candle

52 Al-Maqrīz̄i, Sulūk, II/1, 135/6.

53 Al-Nuwayrī, Nihāyat, XXXII, 212-14; al-Șafadī, Wāfì IV, 277/8 and XXII, 331/2; al-Șafadī, $A^{c} y \bar{a} n$, III, 1293/4; Muhammad b. Shākir al-Kutubī (d. 764/1363), Fawāt al-wafayāt wa-l-dhayl calayhā, 5 vols, ed. Iḥsān ${ }^{\mathrm{c}}$ Abbās, (Beirut, 1973-4), IV, 26; al-Subkī, Tabaqāt, X, 370/1; ' Abd al-Rahīm b. alḤasan al-Asnawī (d. 772/1370), Țabaqāt al-Shāfi ${ }^{c} \bar{l} y a, 2$ vols., ed. ${ }^{\mathrm{c}}$ Abd Allāh Jubūrī, (Baghdad, 1970-1), I, 289; Ibn Kathīr, Bidāya, XIV, 72/3; Ibn Hajar, Durar, III, 214/5; Abū Bakr b. Aḥmad Ibn Qāḍī Shuhba (d. 851/1448), Tabaqāt al-Shāfic ${ }^{c} y a, 4$ vols, ed. ${ }^{~}$ Abd al- ${ }^{c}$ Alīm Khān (Beirut, 1987), I, 275/6; Shams alDīn Dāwūdī (d. 945/1538), Țabaqāt al-Mufassirīn, 2 vols, ed. ' Alī M. ' Umar (Cairo, 1972), I, 438; ' Abd al-Ḥayy b. Aḥmad Ibn al- ${ }^{\mathrm{c}}$ Imād (d. 1089 /1679), Shadharāt al-dhahab fi akhbār man dhahab, 10 vols, eds. 'Abd al-Qādir alArnā̄ūt and Maḥmūd al-Arnā̄ ūṭ, (Beirut, 1986), VIII, 115.

54 For example: Ismā $\bar{c}^{\mathrm{c}} \mathrm{l}$ b. ${ }^{\mathrm{c}} \mathrm{Alī}$ Abū l-Fidāō (d. 732/1331), Al-Mukhtașar fì akhbār al-bashar, 4 vols, ed. n.n., (Cairo, 1907); Ibn al-Dawādārī, Kanz; alMufaḍụal b. Abī l-Faḍāôil (fl. 8/14th century.), Al-Nahj al-sadìd wa-al-durr alfarìd fì mā $b a^{c} d t a^{\supset} r \bar{k} k h$ Ibn al- ${ }^{c} A m \bar{l} d$, edited as: Moufazzal Ibn Abil-Fazaïl, Histoire des sultans mamlouks, Patrologia orientalis 20/1, ed. E. Blochet, (Paris, 1928); Yūsuf Ibn Taghrībirdī (d. 874/1470), Al-Nujūm al-zāhira fì mulūk Miṣr wa-al-Qāhira, 16 vols, eds. Fahīm M. Shaltūt et al. (Cairo, 1929-72).

55 Such as, for example, al-Șafadī, $A^{c} y \bar{a} n$, III, 1293/4; al-Ṣafadī, Wāfì, XXII, 331/2 and IV, 264-84.

56 Most importantly, al-Nuwayrī, Nihāyat, XXXII, 212-14, whose report on the events is the longest. 
scandal' report. This decision is to some degree characteristic of alMaqrīzì's style and his tendency to refashion many episodes of the early Mamlūk period. This can be described as factual unreliability, ${ }^{57}$ but it is here rather understood as a sign of the authorial agency al-Maqrīzì disposed of - an authorial agency that enabled him to make characteristic decisions on what to include and how to include it. With the inclusion of the 'speak to him gently' element, he implicitly linked the confrontation at court to the well-established tradition of the pharaonic narrative element in ruler-scholar confrontations.

In order to understand the logic of al-Maqrīzī's peculiar way of narrating the pharaoh element, it is necessary to examine in more detail two further modifications that distinguished his version from earlier and contemporary versions of the 'candle' anecdote. First, al-Maqrīzī was relatively restrained in criticising al-Bakrī's behaviour. Other authors underlined that al-Bakrī 'commanded the right and forbade the wrong' without any authorisation or stated that al-Bakrī inappropriately attacked his opponent in the affair claiming that he 'behaves provocatively towards the State, disregards it and despises it' ${ }^{58}$ Al-Maqrīzī obliterated most of these passages and saw no need to criticise al-Bakrī in these terms. Rather, al-Maqrizī - uniquely so-stands out with his final citation that blames al-Bakrī not for being too audacious, but rather for finally abasing himself to the sultạn. In the same vein, he criticised alBakrī not for commanding the right and forbidding the wrong without authorisation, but instead for being insincere in its application. In this way al-Maqrīzī represented al-Bakrī not as the trouble maker he is in other versions, but rather as an upright scholar whose shortcomings were that he finally gave in and that he was not sufficiently consistent in his practice. Secondly, al-Maqrīzī has the sulțān acting very much like the tyrant he denies to be. Hereby, he renders the scene more dramatic: the sultạn twice intends to summarily execute the scholar with his sword; he screams and he kicks out the inconvenient scholar-all narrative elements absent in earlier versions. ${ }^{59}$

57 R. Amitai, 'Al-Maqrīzī as a Historian of the Early Mamluk Sultanate (or: Is al-Maqrīz̄i an Unrecognised Historiographical Villain?)', Mamlūk Studies Review, 7/2 (2003), 99-118.

58 Al-Nuwayrī, Nihāyat, XXXII, 212-14.

59 Al-Maqrīzī's contemporary, Ibn Hajar has these elements as well in his Durar, III, 214/5 and they increasingly appear in following works, such as Dāwūdī, Tabaqāt, I, 438. Thus, it seems that these elements originated in alMaqrīzî̀'s period, although it is unclear whether he himself invented them. Their 
Thus, al-Maqrīzī expressed his sympathy for al-Bakrī's audaciousness and his initial steadfastness by substantially rearranging the previous narratives and taking characteristic decisions on including and excluding material that fitted his outlook. It is against this background that his inclusion of the 'speak to him gently' element can be seen. Due to the continuing availability of the original al-Rashīd version, both in alTabarī's chronicle and in later texts, as well as the availability of the secondary versions, a literate audience was aware of this element. However, al-Maqrīzī did not just reproduce the original version in a different setting, but changed it substantially in order to adopt it to his outlook. The inclusion of the 'speak to him gently' element did not serve anymore, as it had served in the original version and its variants, as an element that invoked questions concerning issues such as the relationship between the rulers and religious men and the characteristics of (good) rulership. The main point for al-Maqrīzi was instead to scathe the military, political, and scholarly elite by invoking and reworking a wellknown precedent. The main function of the 'speak to him gently' element now served primarily as a reminder of how dramatically things had changed and deteriorated since the Golden Age of Hārūn al-Rashīd.

Al-Maqrīzī showed this change first and foremost by the fact that the crucial Quranic verse had to be introduced by a scholar, Ibn alMurahhil. ${ }^{60}$ In the original version (and the other primary and secondary versions), on the contrary, it had been the exemplary ruler himself, for example Hārūn al-Rashīd, who had referred to the verse. It was only Ibn Hajar who introduced a similar change in exactly the same period. However, al-Maqrīzì's changes were farther reaching than Ibn Hajar's as even this attempt to calm the ruler is doomed: the sultân grows only angrier at the scholar's attempt to wriggle his way out of the conflict. The wise ruler of the distant past has given place to the tyrannical ruler of the present who is not willing or able to understand the scholars' attempt to give him the upper hand in moral terms.

increasing importance is also visible in a manuscript of Ibn Qāọ̄ Shuhba's biographical dictionary, in which somebody added on the margins additional information on the story (Ibn Qāọī Shuhba, Ṭabaqāt, II, 274, n. 15).

60 Șadr al-Dīn Muhammad b. ' Umar b. Makkī Ibn al-Wakīi/Ibn al-Muraḥhil, (d. 716/1316). On him, see al-Nuwayrī, Nihāyat, XXXII, 249; al-Dhahabī, Ta rīkh, vol. 701-746, 146/7; al-Kutubī, Fawāt, IV, 13-26; al-Șafadī, Wäfì IV, 264-284; al-Subkī, Tabaqāt, IX, 253-267; Ibn Kathīr, Bidāya, XIV, 82/3; Ibn Ḥajar, Durar, IV, 234-41; Ibn Qāạī Shuhba, Țabaqāt, II, 233-4. 
With these changes the crucial issue of the original version is reinterpreted. In the original, the reprimand of the Quranic verse had been aimed at those who were not entitled to criticise the ruler, namely the ascetic, and had implicitly given outstanding religious men the right to do so. In other words, the religious elite was depicted as having the right and the capacity to stand up against the ruler. Al-Maqrīzì certainly agreed that the scholarly elite of the Mamlūk empire had the right to confront the political and military elite. However, in his narrative the scholarly elite had lost the capacity to do so due to their internal divisions. It is the scholar Ibn al-Muraḥil who applies the verse to alBakrī in order to criticise him, and the chief judge Ibn Jamāca supports him. ${ }^{61}$ Only the Mālikī judge Ibn Makhlūf intervenes in favour of alBakrī, but finds no support among the other scholars. ${ }^{62}$ This is expressed even more clearly by the decisive role that al-Maqrīzī ascribed to the military officers - not the scholars-who intervened and interceded with the sulțān in order to save al-Bakrī.

Al-Maqrīzì's version gives the overall impression that the scholars are, due to their internal divisions and their closeness to the ruling elite, devoid of any capacity to intervene. This is an element that is also nearly unique to al-Maqrīzī compared to the other versions of the 'candle' anecdote where the decisive intercession in favour of al-Bakrī was generally undertaken by the scholar Ibn al-Murahhil. ${ }^{63}$ In these versions Ibn al-Murahhil was initially not present at court - only al-Maqrīzī introduced him in the beginning of his version in order to have him citing the 'pharaoh' element. The other authors mentioned instead that Ibn al-Muraḥil came later to court after he had heard about the ruler's harsh verdict and asked the ruler in tears for pardon. In this way al-

61 Muhạmmad b. Ibrāhīm b. Sa d Allāh Badr al-Dīn (d. 733/1333). On him, see al-Dhahabī, Ta rīkh, vols 701-46, 289-91; al-Șafadī, Wāfì, II, 18-20; Ibn Kaṭhīr, Bidāya, XIV, 171; Ibn Hajar, Durar, III, 367-9.

62 c Alī b. Makhlūf b. Nāhị̣ al-Nuwayrī al-Mālikī (d. 718/1318). Al-Mālikī was chief judge from 685/1286 to 718/1318. On him, see al-Dhahabī, Ta rīkh, vols 701-46, 159; al-Șafadī, Wāfì, XXII, 189/90; al-Șafadī, $A^{c} y \bar{a} n$, III, 1267/8; Ibn Kathīr, Bidāya, XIV, 93; Ibn Hajar, Durar, III, 202.

63 Only al-Nuwayrī, Nihāyat, XXXII, 212-14 does not mention Ibn alMuraḥhil at all. On Ibn al-Muraḥhil's intercession, cf. al-Kutubī, Fawāt, IV, 26; al-Șafadī, $A^{c} y \bar{a} n$, III, 1293/4; al-Șafadī, Wāfì XXII, 331/2 and IV, 264-284; alSubkī, Tabaqāt, X, 370/1. Ibn Kathīr, Bidāya, XIV, 72/3, briefly refers in his summary version of the events to the officers who interceded in favour of alBakrī. 
Maqrīzī ascribed the agency for interceding with the ruler to the military elite, and wrote Ibn al-Murahhil out of the final scene. In addition, he depicts Ibn al-Muraḥil as taking a stance against the 'upright' al-Bakrī. Al-Maqrīzī's decision to rework Ibn al-Murahhil's role was based on the latter's close relationship to the ruling elite during different stages of his career. ${ }^{64}$

With this anecdote, al-Maqrīzī expressed his perception of Mamlūk society that he had started to see in increasingly negative terms, after his early career had come to an end with the execution of his Mamlūk friend and patron Fath Allāh in 816/1413.65 After this, he gradually withdrew from public life and devoted himself to the composition of his main works, among them al-Sulu k, from which the above-cited passage is taken. He expressed in these works his increasingly distanced position vis-à-vis the military, political and social elite. The structure and the critical tone of his works reflect his ill-feelings towards what he perceived to be the corrupt political system of his time. He combined this with sympathy for groups that opposed and actively challenged the wrong-doings of power holders of their day. Most noteworthy, his oeuvre shows his positive attitude towards groups such as the Zāhirī madhhab and the Alids. His positive depiction of these groups was not rooted in any covert adherence to their religious and legal interpretations, but in his admiration of their 'militant' spirit. During the Mamlūk era, the term 'Zāhirî', for instance, referred less to those adhering to the legal tenants of this school, but more to certain politico-religious concepts that caused revolt or fitna. ${ }^{66}$ Initially, al-Maqrīzi had pursued the normal career within Mamlūk society although he shared with many

64 On his close relationship with the viceroy al-Afram and the sulțān, see S. A. Jackson, 'Ibn Taymiyyah on Trial in Damascus', Journal of Semitic Studies, 39/1 (1994), 46-7. Ibn al-Murahhil was also intimately involved in the conflicts between the Sulțān Muhammad b. Qalāwūn and his rival al-Malik al-Muzaffar Baybars.

65 On his career, see A. F. Broadbridge, 'Academic Rivalry and the Patronage System in Fifteenth-Century Egypt: Al- ${ }^{\mathrm{c}}$ Aynī, al-Maqrīzī, and Ibn Hajar al- 'Asqalānī', Mamlūk Studies Review, 3 (1999), 85-107.

66 On the fourteenth-century 'Zahiri' revolt in Damascus that was not linked to legal doctrine but to the issue of legitimate political power, see L. Wiederhold, 'Legal-Religious Elite, Temporal Authority, and the Caliphate in Mamluk Society: Conclusions Drawn from the Examination of a "Zahiri Revolt” in Damascus in 1386', International Journal of Middle East Studies, 31 (1999), 203-35. 
contemporaries a somewhat distanced stance towards the Mamlūk elite. What differentiated al-Maqrīzī from other scholars were these sympathies for groups that commanded the right and forbid the wrong. ${ }^{67}$

Al-Maqrīzì's reshaping of the anecdote points to one of the more important issues during the Mamlūk period, the role of religious scholars in political dynamics. The versions of al-Tabarī, Ibn ${ }^{\mathrm{C}} \mathrm{Abd}$ Rabbih and Ibn al-Jawzī with al-Rashīd and al-Ma ${ }^{9}$ mūn as the rulers approached the same issue in the widest sense by asking who had the right to criticise the ruler and how the latter ought to react to inappropriate criticism. However, al-Maqrīzī's version raises a different issue, namely the degree to which scholars had the right to impose on the political-military elite its norms with regard to concrete fields of policy, not merely in the sense of a general admonishment. This was a key issue during the period in which the anecdote is set, due to the manifold conflicts between State authorities and Ibn Taymiya. Indeed, it is certainly not by chance that Ibn Hajar's contemporary version of the anecdote had Ibn Taymiya as its protagonist on the scholarly side. The sultān had released Ibn Taymīya from his second prison spell in Egypt five years prior to the 'candle scandal', and the scholar returned subsequently to Syria only to become embroiled in another prolonged conflict with the authorities some years later. Most of the individuals who were mentioned in the framework of the 'candle scandal' were in one way or the other also involved in the Ibn Taymīya conflict. ${ }^{68}$ In this sense, al-Maqrīzī's re-narration of the court confrontation in the framework of the 'candle scandal', and especially the fusion of this event with the 'speak to him gently' anecdote, can be read as a highly topical comment on one of the central issues during the period in which the anecdote was placed. The peculiar way in which al-Maqrīzī employed the 'speak to him gently' anecdote can be read in conjunction with his peculiar perception of society. His

67 N. Rabbat, 'Who Was al-Maqrīzī? A Biographical Sketch', Mamlūk Studies Review, 7/2 (2003), 1-19.

68 Al-Bakrī was renown for his sharp criticism of Ibn Taymīya (cf. alDhahabī, Ta rīkh, vols 701-46, 216; Ibn Kathīr, Bidāya, 62). Ibn alMuraḥhil/Ibn al-Wakīl was not on particular good terms with Ibn Taymīya and often engaged in public disputations with him (cf. Jackson (1994), 46/7; alKutubī, Fawāt, IV, 14; al-Subkī, Tabaqāt, IX, 253-267; Ibn Kathīr, Bidāya, XIV, 82/3. Ibn Makhlūf was held responsible for the 705/1305 mihnna against Ibn Taymìya. See, D. P. Little, 'The Historical and Historiographical Significance of the Detention of Ibn Taymiyya', International Journal of Middle East Studies, 4/3 (1973), 311-27, (p. 324). 
narrative strategy allowed him to express his critical view of the Mamlūk elite and, more importantly, of the scholarly elite who in his eyes did not fulfil their role as guardians of society.

\section{Conclusion}

The discussion of the 'speak to him gently' anecdote has shown how narrative devices travelled across genres, periods, and regions. This process was not one of simply 'borrowing', but draws attention to the degree of textual agency that authors of pre-modern historiographical texts disposed of and made use of. They took wide-ranging liberties in adapting the anecdote into their respective narratives and in reworking it in the process. Crucial elements of the anecdote, such as the protagonists, the place, and the chronological setting were easily exchanged, without obliterating the reference to the 'original' version. The combination of literary approaches with a consideration of the social context in which the respective version was produced has allowed us to understand better the metamorphosis of narrative structures that were employed to frame the anecdote and of the changing layers of meaning that were assigned to it. By reworking the factual elements the authors were able to ascribe to the anecdote, meanings that ranged from issues such as the right to criticise the ruler, via the relationship between scholars and rulers and the ruler's forbearance to the failure of the scholarly community to stand up against unjust rulers.

The historical-literary journey of the pharaoh figure did not stop with al-Maqrīzī's text in the late Middle Ages. In subsequent periods, it remained an important device that was employed in Arabic historical narratives. ${ }^{69}$ The importance of this element until the present-not only in historiography, but in a multitude of genres - shows the narrative flexibility that is inherent to such devices. As much as the figure of the pharaoh gained a multitude of meanings in the pre-modern period, it has been subject to new readings, such as nationalistic interpretations, in the modern era. ${ }^{70}$ Further studies of these devices will certainly underline the

69 See, for example, A. Geier, Von den Pharaonen zu den Khediven: Ägyptische Geschichte nach den Hițaț des ${ }^{c}$ Alī Mubārak, (Frankfurt, 1998), 50-1.

70 On modern interpretations of the pharoah, see A. Douglas and F. MaltiDouglas, 'Film and Pharaonism: Shād̄̄ c Abd al-Salām's Eloquent Peasant', in Tradition and Modernity in Arabic Literature, ed. I. J. Boullata and T. DeYoung (Fayetteville, 1997), 193-205; D. M. Reid, Whose Pharaohs? Archaeology, Museums, and Egyptian National Identity from Napoleon to World War I (Berkeley, 2002); M. Haarmann, 'Das moderne Ägypten und seine pharaonische Vergangenheit' (unpubl. PhD thesis, University of Freiburg, 1991). 
continuous tradition of Arabic historiography across periods and regions. However, the study of this continuity is not an end by itself. Rather, it is of relevance because of the ways it highlights the breaks, shifts, and changes in the significance that such elements held in their respective contexts. It is in this sense that reflections on narrativity and social context, that is to say, on the 'social logic' of the text, render historiographical texts a rich source for the study of the societies with which we are concerned. 